\title{
Antibiotic Susceptibility Manner of the Bacteria Causes Urinary Tract Infections in Basra, South Iraq
}

\author{
Eman T. Ali ${ }^{1}$ (D) Asia S. Abdullah ${ }^{2 *}$ (D) and Rana M. Abdulnabi Keshi ${ }^{1}$ (D) \\ ${ }^{1}$ Department of Clinical Laboratory Sciences, Institute of Pharmacy, Basra, Iraq. ${ }^{2}$ Department of Pharmacology \\ and Toxicology, Institute of Pharmacy, Basra, Iraq.
}

\begin{abstract}
Infections of the urinary tract are involved with the common infectious diseases in the population, by the yearly occurrence of 18 per 1000 people. This study carried out to determine the causative pathogenic bacteria of the urinary tract infections (UTIs) and to measure the frequency and susceptibility outline of different bacteria causing UTIs that acquired by the community in Basra city south Iraq. This study recruit102 persons ( 77 females with 25 males) with the age range of (15-55) years old, clinically suspected for UTI. Clean midstream urine gathered from the patients in a sterile tube and tested by the use of typical procedures. Kirby-Bauer technique used to test antibiotic sensitivity of the isolated pathogenic bacteria according to the Clinical and Laboratory Standards Institute (CLSI) guidelines. Examination of centrifuged urine samples microscopically revealed 42 (31 females with 11 males) had pyuria (a significant number of pus cells) while $\mathbf{5 0}$ (37 females with 13 males) had scarcer pus cells. Eight urine samples ( 6 females and 2 males) had calcium oxalate crystals and 20 samples had numerous epithelial cells. Combi-9 (Medi-Test) used for urinalysis revealed 58 samples (44 females with 14 males) had protein, of which 37 (29 females and 8 males) with growth and 21 without growth. Gram stain besides biochemical tests used for identification of the pathogens, among the positive samples, the most popular pathogens identified as Escherichia coli (49.0\%), Klebsiella species (19.6\%), Proteus species (11.8\%), Pseudomonas aeruginosa (10.8\%), and Staphylococcus aureus (8.8\%).Regarding to the isolated Gram-negative bacteria, all are resistant to Amikacin (AK), Rifampicin (RA), Nitrofurantoin (F), Trimethoprim + Sulfamethoxazole (SXT), Novobiocin (NV), Nalidixic Acid (NA), Chloramphenicol (C), Tetracycline (TE), Cefepime (FEP), Bacitracin (B), Erythromycin (E) and Streptomycin (S). However, some isolates were less resistant to Amoxicillin (AX), Ceftizoxime (ZOX), Cefoxitin (FOX), Gentamicin (GM), and Cefotaxime (CTX). Gram-positive isolates were resistant to all antimicrobials except Amikacin, Trimethoprim + Sulfamethoxazole, Gentamycin and Chloramphenicol. Females infected with UTIs more than males in Basrah, South Iraq. E. coli was the major isolate, as found in other studies.

Keywords: Urinary tract infections (UTIs), Pathogenic bacteria, Basra, Antibiotic sensitivity
\end{abstract}

*Correspondence: asia_abdullah65@yahoo.com

(Received: September 28, 2019; accepted: February 20, 2020)

Citation: Eman T. Ali, Asia S. Abdullah and Rana M. AbdulnabiKeshi, Antibiotic Susceptibility Manner of the Bacteria Causes Urinary Tract Infections in Basra, South Iraq, J. Pure Appl. Microbiol., 2020; 14(1):541-546. https://doi.org/10.22207/JPAM.14.1.56

(C) The Author(s) 2020. Open Access. This article is distributed under the terms of the Creative Commons Attribution 4.0 International License which permits unrestricted use, sharing, distribution, and reproduction in any medium, provided you give appropriate credit to the original author(s) and the source, provide a link to the Creative Commons license, and indicate if changes were made. 


\section{INTRODUCTION}

Infections of the urinary tract are involved

with the common infectious diseases in the population, by the yearly occurrence of 18 per 1000 person ${ }^{1}$. Currently, it considered as one of the most popular diseases affecting people of all age groups from the neonate to the geriatric ${ }^{2}$. Furthermore, UTI found as the major ordinary cause of the hospital-acquired infections between patients ${ }^{3}$. Complications of UTI involve pyelonephritis that needs hospitalization and can cause permanent renal damage. It reported that UTIs are the most popular infections in women, frequently caused by pathogenic bacteria from fecal flora (mainly Escherichia coli) that raises the urethra to infect the bladder ${ }^{4}$. UTI in men is frequently complicated because they commonly occur in old age patients in the state of abnormalities of the urinary tract and only a little of younger men affected ${ }^{5}$. In the USA, a developed country, there is about eight million physician visits per year for UTIs only ${ }^{6}$. The condition is worst in developing countries, particularly in the poor areas, clinicians frequently start the antibiotic treatment the the availability of the laboratory diagnostic test results ${ }^{7}$.

Currently, there is an increase in the rate of antibiotic resistance among UTIs pathogens, particularly in developing countries. Studies indicated that there is an increasing rate of resistance of uropathogens to the ordinary prescribed antibiotics, reducing therapeutic potential ${ }^{8,9}$. Therefore, the precise investigation of UTI pathogens and reporting antibiotic susceptibility patterns is essential for the selection of suitable drugs for efficient treatment. That is why this research is essential globally. Regardless of the guidelines published for the better choice of an antimicrobial drug and length of therapy,studies showed large differences in prescribing practices ${ }^{10-12}$

No recent information particularly on the antibiotic susceptibility manners of urinary pathogens amongst UTIs patients in Basra. Therefore, this study carried out to determine the causative pathogenic bacteria of the urinary tract infections (UTIS) and to measure the frequency and susceptibility outline of different bacteria causing UTIs that acquired by the community in Basra city south Iraq.

\section{MATERIALS AND METHODS \\ Sample collection}

This study carried out during the term from February to May 2018 and the patients selected during their visit to the outpatient clinic of Basra teaching hospital in Basra, Iraq. Institutional Ethical Committee accepted the research and informed consent achieved from the subjects. Patients with clinical symptoms of UTIs, with no record of antibiotic use within 14 days before their attendance were included in this study. The exclusion criteria were diabetes mellitus, renal disorders and infectious diseases. In addition, the patients on antibiotics or on corticosteroid therapy excluded. Furthermore, patients who not provide informed consent excluded from the study. Recruited patients provided with sterile containers with a broad mouth and they informed on the way of collecting a mid-stream urine sample.

From 150 patients, 102 selected according to this study inclusion criterion. About (25) males with (77)females, in the age group of (15-55) years old (mean, 34.01years). Clean mid-stream urine gathered from the patients in a sterile tube (4- $5 \mathrm{ml}$ ) and transported directly to the lab for examination. Rules for suitable specimen gathering given to patients on a writtencard ${ }^{13}$.

\section{Urine analysis}

Collected urine samples investigated for their turbidity and colour macroscopically, then all samples were centrifuged and the precipitates investigated microscopically for blood cells, epithelial cells, Schistosoma eggs, protozoa, yeasts and crystal forms.

Inoculation of primary isolation culture media

Each fresh urine sample inoculated on various media by the use of loop, media includes blood agar (Himedia, India), Nutrient agar (Merck, Germany) and McConkey agar (Merck, Germany), and then all inoculated media incubated at $37^{\circ} \mathrm{C}$ for one day in aerobic condition, after that the colonies number counted. Subsequently, isolated bacteria streaked four times on the identical media. Calibrated loop method used for colony count using the measured quantity of urine, inoculated to the nutrient agar medium(Merck, Germany).Colony counts that show bacterial growth equal /more than $104 \mathrm{CFU} / \mathrm{ml}$ of urine with single or two pathogens were regarded positive. Experiments were repeated if the results between 
102-104 CFU/ml, and results were negative if it is less than $102 \mathrm{CFU} / \mathrm{ml}$ of urine. Colony counts yielding bacterial growth equivalent to or extra than 104 CFU/ml of urine ( $\geq 100,000$ colonies), single possible pathogen or for each of two possible pathogens regarded as UTI positive and a result repeated if it is $102-104 \mathrm{CFU} / \mathrm{ml}$. Negative UTI results fewer than $102 \mathrm{CFU} / \mathrm{ml}$ of urine.

\section{Identification of Bacteria}

Gram stain besides biochemical tests used for the identification of the pathogens, based on cultural characteristics. Clean isolates of pathogenic bacteria initially recognized by colony morphology, catalase test and gram stain. Then the doubted colonies investigated under the light microscope for their colours, shapes and arrangements, in addition to gram stain analysis. All of the isolated bacteria identified using classical biochemical tests ${ }^{13-15}$.

\section{Antibiotic Susceptibility}

Kirby-Bauer technique used to test antibiotic sensitivity of the isolated pathogenic bacteria according to the Clinical and Laboratory Standards Institute (CLSI) guidelines. $0.1 \mathrm{~mL}$ of 0.5 MacFarl and (about 107CFU/mL) consistent isolates seeded on Sterile Mueller-Hinton Agar plates using a sterile curved glass rod and left on the bench for about 30 minutes to dry. By the use of sterile forceps antibiotic discs placed on the plates, all plates incubated for $18-20 \mathrm{~h}$ at $35-37^{\circ} \mathrm{C}$. After that, inhibition zone diameters documented and regarded following CLSI accepted standard guidelines $^{16}$.

The subsequent antimicrobial drugs tested for both Gram-positive and Gram-negative bacteria. These are Amikacin $(10 \mu \mathrm{g})$, Amoxicillin $(25 \mu \mathrm{g})$, Rifampicin $(5 \mu \mathrm{g})$, Nitrofurantoin $(300 \mu \mathrm{g})$, Trimethoprim(1.25 $\mathrm{g})+$ Sulfamethoxazole
$(23.75 \mu \mathrm{g})$, Cefatizoxime $(30 \mu \mathrm{g})$, Cefoxitin $(30 \mu \mathrm{g})$, Novobiocin $(30 \mu \mathrm{g})$, Nalidixic Acid $(30 \mu \mathrm{g})$, Gentamicin $(10 \mu \mathrm{g})$, Chloramphenicol $(30 \mu \mathrm{g})$, Cefotaxime $(30 \mu \mathrm{g})$, Tetracycline $(30 \mu \mathrm{g})$, Cefepime $(30 \mu \mathrm{g})$, Bacitracin $(0.4 \mu \mathrm{g})$, Erythromycin $(15 \mu \mathrm{g})$ and Streptomycin $(10 \mu \mathrm{g})$.

\section{RESULTS}

Isolation and description of bacterial isolates

Approximately 102 urine samples (77 from females and 25 from males) with the age range of (15-55) years old (mean, 34.01 years) were collected from the outpatient clinic of Basra teaching hospital in Basra, Iraq. Examination of centrifuged urine samples microscopically revealed 42 ( 31 females with 11 males) had pyuria (a significant number of pus cells) while 50 (37 females with 13 males) had scarcer pus cells. Eight urine samples ( 6 females and 2 males) had calcium oxalate crystals and 20 samples had numerous epithelial cells.

Combi-9 (Medi-Test) used for urinalysis revealed 58 samples (44 females with 14 males) had protein, of which 37 (29 females and 8 males) with growth and 21 without growth. Gram stain besides biochemical tests used for identification of the pathogens, among the positive samples, the most popular pathogens identified as Escherichia coli (49.0\%), Klebsiella species (19.6\%), Proteus species (11.8\%), Pseudomonas aeruginosa (10.8\%), and Staphylococcus aureus (8.8\%) (Table $1)$.

Antimicrobial susceptibility profile of urine isolates

Isolated Gram-negative bacteria were all resistant to Amikacin (AK), Rifampicin (RA), Nitrofurantoin (F), Trimethoprim + Sulfamethoxazole (SXT), Novobiocin (NV), Nalidixic

Table 1. Gender wise allocation and occurrence of pathogens producing urinary tract infections (UTIs) in Basra, south Iraq

\begin{tabular}{lllll}
\hline & Name of isolates & Male (\%) & Female (\%) & Total (\%) \\
\hline \multirow{2}{*}{ Grame -ve } & Escherichia coli & $10(40)$ & $40(51.9)$ & $50(49.0)$ \\
& Klebsiella pneumonia & $7(28)$ & $13(16.9)$ & $20(19.6)$ \\
& Proteus mirabilis & $2(8)$ & $10(13)$ & $12(11.8)$ \\
& Pseudomonas aeruginosa & $2(8)$ & $9(11.7)$ & $11(10.8)$ \\
Grame+ ve & Staphylococcus aureus & $4(16)$ & $5(6.5)$ & $9(8.8)$ \\
& Total & 25 & 77 & 102 \\
\hline Journal of Pure and Applied Microbiology & 543 & & & www.microbiologyjournal.org
\end{tabular}


Acid (NA), Chloramphenicol (C), Tetracycline (TE), Cefepime (FEP), Bacitracin (B), Erythromycin (E) and Streptomycin (S). However, some isolates were less resistant to Amoxicillin (AX), Ceftizoxime (ZOX), Cefoxitin (FOX), Gentamicin (GM), and Cefotaxime (CTX).Gram-positive isolates were resistant to all antimicrobials except Amikacin, Trimethoprim + Sulfamethoxazole, Gentamycin and Chloramphenicol (Tables 2 and 3 ).

\section{DISCUSSION AND CONCLUSION}

Identification of the pathogens causing UTIs and their sensitivity manner is very essential in the management of UTIs cases. Our main objective was to recognize the problem of UTIs in Basra by using a simple survey approach. Information bias could not significantly affect the results of the study because the hospital staffs were not fully aware of the aims of the study. Detection bias

Table2. Antimicrobial sensitivity of the isolated bacteria from urine samples of102UTI patientsin Basra, south of Iraq

\begin{tabular}{|c|c|c|c|c|c|c|c|c|c|c|}
\hline \multirow[t]{3}{*}{ Antimicrobials } & \multicolumn{10}{|c|}{ \%of Susceptible (S)and resistant (R) bacterial isolates } \\
\hline & \multicolumn{2}{|c|}{ E.coli } & \multicolumn{2}{|c|}{$\begin{array}{c}\text { Klebsiella } \\
\text { pneumonia }\end{array}$} & \multicolumn{2}{|c|}{$\begin{array}{l}\text { Proteus } \\
\text { mirabilis }\end{array}$} & \multicolumn{2}{|c|}{$\begin{array}{r}\text { Pseudomonas } \\
\text { aeruginosa } \\
\end{array}$} & \multicolumn{2}{|c|}{$\begin{array}{c}\text { Staphylococcus } \\
\text { aureus }\end{array}$} \\
\hline & $\mathrm{S}$ & $\mathrm{R}$ & $S$ & $\mathrm{R}$ & $\mathrm{S}$ & $\mathrm{R}$ & $S$ & $\mathrm{R}$ & $S$ & $\mathrm{R}$ \\
\hline Amikacin & 83.2 & 16.8 & 32.0 & 68.0 & 84.1 & 15.9 & 36.3 & 63.7 & 68.0 & 32.0 \\
\hline Amoxicillin & 42.4 & 57.6 & 17.8 & 82.2 & 10.0 & 90.0 & 13.6 & 86.4 & 32.8 & 67.2 \\
\hline Rifampicin & 7.7 & 92.3 & 11.0 & 89.0 & 11.8 & 88.2 & 18.7 & 81.3 & 35.8 & 64.2 \\
\hline Nitrofurantoin & 55.0 & 45.0 & 47.1 & 52.9 & 38.0 & 62.0 & 21.6 & 78.4 & 39.7 & 60.3 \\
\hline $\begin{array}{l}\text { Trimethoprim + } \\
\text { Sulfamethoxazole }\end{array}$ & 48.5 & 51.5 & 33.6 & 66.4 & 44.8 & 55.2 & 10.8 & 89.2 & 82.3 & 17.7 \\
\hline Ceftizoxime & 55.9 & 44.1 & 53.8 & 46.2 & 44.1 & 55.9 & 54.8 & 45.2 & 47.3 & 52.7 \\
\hline Cefoxitin & 53.7 & 46.3 & 54.6 & 45.4 & 52.0 & 48.0 & 51.6 & 48.4 & 46.1 & 53.9 \\
\hline Novobiocin & 25.0 & 75.0 & 27.4 & 72.6 & 41.4 & 58.6 & 31.0 & 69.0 & 35.2 & 64.8 \\
\hline Nalidixic Acid & 30.7 & 69.3 & 38.5 & 61.5 & 43.5 & 56.5 & 12.8 & 87.2 & 15.5 & 84.5 \\
\hline Gentamicin & 21.7 & 78.3 & 84.2 & 15.8 & 67.0 & 33.0 & 51.7 & 48.3 & 60.0 & 40.0 \\
\hline Chloramphenicol & 43.2 & 56.8 & 43.0 & 57.0 & 40.2 & 59.8 & 40.3 & 59.7 & 74.2 & 25.8 \\
\hline Cefotaxime & 56.2 & 43.8 & 51.8 & 48.2 & 54.0 & 46.0 & 45.0 & 55.0 & 36.2 & 63.8 \\
\hline Tetracycline & 39.7 & 60.3 & 22.0 & 78.0 & 22.5 & 77.5 & 23.6 & 76.4 & 46.6 & 53.2 \\
\hline Cefepime & 40.4 & 59.6 & 25.9 & 74.1 & 26.9 & 73.1 & 19.5 & 80.5 & 33.1 & 66.9 \\
\hline Bacitracin & 10.8 & 89.2 & 11.9 & 88.1 & 27.6 & 72.4 & 20.7 & 79.3 & 31.0 & 69.0 \\
\hline Erythromycin & 4.7 & 95.3 & 11.0 & 89.0 & 20.9 & 79.1 & 33.6 & 66.4 & 40.0 & 60.0 \\
\hline Streptomycin & 7.1 & 92.9 & 9.0 & 91.0 & 20.0 & 80.0 & 30.8 & 69.2 & 23.4 & 76.6 \\
\hline
\end{tabular}

Amikacin (10 $\mu \mathrm{g})$, Amoxicillin $(25 \mu \mathrm{g})$, Rifampicin $(5 \mu \mathrm{g})$, Nitrofurantoin $(300 \mu \mathrm{g})$, Trimethoprim $(1.25 \mu \mathrm{g})+$ Sulfamethoxazole

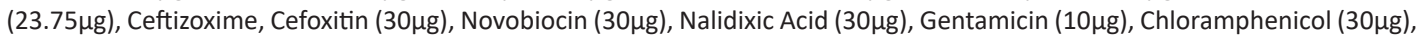
Cefotaxime $(30 \mu \mathrm{g})$, Tetracycline $(30 \mu \mathrm{g})$, Cefepime $(30 \mu \mathrm{g})$, Bacitracin $(0.4 \mu \mathrm{g})$, Erythromycin $(15 \mu \mathrm{g})$ and Streptomycin $(10 \mu \mathrm{g})$

Table 3. Antimicrobial sensitivity manner for pathogens producing urinary tract infections (UTIs) in Basra, south Iraq

\begin{tabular}{lllllllllllllllllllll}
\hline Isolates & AK & AX & RA & F & SXT & ZOX FOX & NV & NA & GM & C & CTX & TE & FEP & B & E & S \\
\hline E.Coli & $\mathrm{R}$ & $\mathrm{R}$ & $\mathrm{R}$ & $\mathrm{R}$ & $\mathrm{R}$ & $\mathrm{R}$ & $\mathrm{R}$ & $\mathrm{R}$ & $\mathrm{R}$ & $\mathrm{R}$ & $\mathrm{R}$ & $\mathrm{R}$ & $\mathrm{R}$ & $\mathrm{R}$ & $\mathrm{R}$ & $\mathrm{R}$ & $\mathrm{R}$ \\
Klebsiella pneumonia & $\mathrm{R}$ & $\mathrm{R}$ & $\mathrm{R}$ & $\mathrm{R}$ & $\mathrm{R}$ & $\mathrm{R}$ & $\mathrm{R}$ & $\mathrm{R}$ & $\mathrm{R}$ & $\mathrm{S}$ & $\mathrm{R}$ & $\mathrm{R}$ & $\mathrm{R}$ & $\mathrm{R}$ & $\mathrm{R}$ & $\mathrm{R}$ & $\mathrm{R}$ \\
proteus mirabilis & $\mathrm{R}$ & $\mathrm{S}$ & $\mathrm{R}$ & $\mathrm{R}$ & $\mathrm{R}$ & $\mathrm{R}$ & $\mathrm{R}$ & $\mathrm{R}$ & $\mathrm{R}$ & $\mathrm{R}$ & $\mathrm{R}$ & $\mathrm{R}$ & $\mathrm{R}$ & $\mathrm{R}$ & $\mathrm{R}$ & $\mathrm{R}$ & $\mathrm{R}$ \\
Pseudomonas aeruginosa & $\mathrm{R}$ & $\mathrm{R}$ & $\mathrm{R}$ & $\mathrm{R}$ & $\mathrm{R}$ & $\mathrm{R}$ & $\mathrm{R}$ & $\mathrm{R}$ & $\mathrm{R}$ & $\mathrm{R}$ & $\mathrm{R}$ & $\mathrm{R}$ & $\mathrm{R}$ & $\mathrm{R}$ & $\mathrm{R}$ & $\mathrm{R}$ & $\mathrm{R}$ \\
Staphylococcus aureus & $\mathrm{R}$ & $\mathrm{R}$ & $\mathrm{R}$ & $\mathrm{R}$ & $\mathrm{R}$ & $\mathrm{R}$ & $\mathrm{R}$ & $\mathrm{R}$ & $\mathrm{R}$ & $\mathrm{S}$ & $\mathrm{R}$ & $\mathrm{R}$ & $\mathrm{R}$ & $\mathrm{R}$ & $\mathrm{R}$ & $\mathrm{R}$ & $\mathrm{R}$ \\
\hline
\end{tabular}

Amikacin (AK), Amoxicillin (AX), Rifampicin (RA), Nitrofurantoin (F), Trimethoprim + Sulfamethoxazole (SXT), Ceftizoxime (ZOX), Cefoxitin (FOX), Novobiocin (NV), Nalidixic Acid (NA), Gentamicin (GM), Chloramphenicol (C), Cefotaxime (CTX), Tetracycline (TE), Cefepime (FEP), Bacitracin (B), Erythromycin (E) and Streptomycin (S). 
could affect the results because certain important laboratory investigations were not available. More advanced explanations sometimes need clinical and laboratory information which is not available in our hospitals regularly.

In this study, the most popular pathogenic bacteria isolated from the urine was Escherichia coli- $49.0 \%$, followed by Klebsiella pneumonia$19.6 \%$, Proteus mirabilis- $11.8 \%$, Pseudomonas aeruginosa- $10.8 \%$ and Staphylococcus aureus$8.8 \%$. The isolation rate of pathogenic bacteria from urine samples as found in other studies in other places published recently. E. coli prevailed among the isolated bacteria, account for $49 \%$ of the positive samples.

The majority of UTIs documented from females in this study, representing that women more than men expected to develop UTIs. These results in conformity, with the results of comparable studies.

There is a global concern about antibacterial resistance. Data on antibiotic use in the hospital concerned obviously designated the lack of antibiotic prescribing policy. The plurality of UTIs treated experiential, particularly in developing countries where patients cannot have laboratory tests done or consult a doctor. Ampiclox and cefotaxime were given to the patients frequently, because of the availability of these antibiotics in hospital pharmacy and because of their wideranging spectrum of activity. Second and thirdgeneration cephalosporins are expensive drugs, and there are frequent economic restrictions. Other antibiotics that are widely used in the treatment of various infections are Erythromycin and Tetracycline, possibly because of their low cost and their good clinical efficiency. Local sensitivity manner of bacteria causing UTIs should be existing to recommend suitable antibiotics.

Isolated E. coli strains (48.5\%) all and other species were resistant to sulfamethoxazoletrimethoprim, these study findings are consistent with earlier studies finding ${ }^{17,18}$. These results are possible because of the frequent use of these antimicrobial drugs in the treatment of infections acquired from the community.

Moderate sensitivity to third-generation cephalosporins and aminoglycosides $(>50 \%)$ in the majority of isolates, as well as their pharmaco kinetic characteristics, causes them to be the first line of treatment for UTI infections until microbiological test results are available.

\section{ACKNOWLEDGMENTS}

Authors would like to acknowledge the staff of outpatient's clinic of Basra teaching hospital in Basra, Iraq for their kind help in patient selection.

\section{CONFLICT OF INTEREST}

The authors declare that there is no conflict of interest.

\section{FUNDING}

None.

\section{AUTHORS' CONTRIBUTION}

All authors listed have made a substantial, direct and intellectual contribution to the work, and approved it for publication.

\section{DATA AVAILABILITY}

All datasets generated or analyzed during this study are included in the manuscript and/or the Supplementary Files.

\section{ETHICS STATEMENT}

Institutional Ethical Committee accepted the research and informed consent achieved from the subjects.

\section{REFERENCES}

1. Hsueh PR, Hoban DJ, Carmeli Y, Chen SY, Desikan S, Alejandria M, Ko WC, Binh TQ: Consensus review of the epidemiology and appropriate antimicrobial therapy of complicated urinary tract infections in AsiaPacific region. J Infect., 2011; 63: 114-23. https://doi. org/10.1016/j.jinf.2011.05.015

2. Kunin CM. Urinary tract infections in females. Clinical Infectious Diseases, 1994; 18 (1): 1-0. https://doi. org/10.1093/clinids/18.1.1

3. Shilpi T, Ahmed MN, Huq SA, Baul SK, Khatun M. Isolation of bacteria causing urinary tract infections and their antibiotic susceptibility profile at Anwer Khan Modern Medical College Hospital. Anwer Khan Modern Medical College Journal, 2013; 4(2): 23-7. https://doi. org/10.3329/akmmcj.v4i2.16938

4. Flores-Mireles AL, Walker JN, Caparon M, Hultgren SJ. Urinary tract infections: epidemiology, mechanisms of infection and treatment options. Nature Reviews Microbiology, 2015; 13 (5): 269-84. https://doi. org/10.1038/nrmicro3432

5. Nicolle LE. Complicated urinary tract infection in adults. Can J Infect Dis Med Microbiol, 2005; 16 (6): 349-60. 
https://doi.org/10.1155/2005/385768

6. Gonzalez CM, Schaeffer AJ. Treatment of urinary tract infection: what's old, what's new, and what works. World journal of urology, 1999; 17(6): 372-82. https:// doi.org/10.1007/s003450050163

7. Dibua UM, Onyemerela IS, Nweze EI. Frequency, urinalysis and susceptibility profile of pathogens causing urinary tract infections in Enugu State, southeast Nigeria. Revista do Instituto de Medicina Tropical de Sao Paulo, 2014; 56(1): 55-9. https://doi. org/10.1590/S0036-46652014000100008

8. Kahlmeter G, Menday P. Cross-resistance and associated resistance in 2478 Escherichia coli isolates from the Pan-European ECO. SENS Project surveying the antimicrobial susceptibility of pathogens from uncomplicated urinary tract infections. Journal of Antimicrobial Chemotherapy, 2003; 52(1): 128-31. https://doi.org/10.1093/jac/dkg280

9. Zhanel GG, Hisanaga TL, Laing NM, DeCorby MR, Nichol KA, Weshnoweski B, Johnson J, Noreddin A, Low $D E$, Karlowsky JA, Hoban DJ. Antibiotic resistance in Escherichia coli outpatient urinary isolates: final results from the North American Urinary Tract Infection Collaborative Alliance (NAUTICA). International journal of antimicrobial agents, 2006; 27(6): 468-75. https:// doi.org/10.1016/j.ijantimicag.2006.02.009

10. Gupta K, Hooton TM, Naber KG, Wullt B, Colgan R, Miller LG, Moran GJ, Nicolle LE, Raz R, Schaeffer AJ, Soper DE. International clinical practice guidelines for the treatment of acute uncomplicated cystitis and pyelonephritis in women: a 2010 update by the Infectious Diseases Society of America and the European Society for Microbiology and Infectious Diseases. Clinical Infectious Diseases, 2011; 52 (5): e103- e120. https://doi.org/10.1093/cid/ciq257
11. Abbo L, Hooton T. Antimicrobial stewardship and urinary tract infections. Antibiotics, 2014; 3(2): 174-92. https://doi.org/10.3390/antibiotics3020174

12. Spoorenberg V, Geerlings SE, Geskus RB, de Reijke TM, Prins JM, Hulscher ME. Appropriate antibiotic use for patients with complicated urinary tract infections in 38 Dutch Hospital Departments: a retrospective study of variation and determinants. BMC Infectious Diseases, 2015; 15(1): 505. https://doi.org/10.1186/ s12879-015-1257-5

13. Mandell GL, Bennett JE, Dolin R. Principles and practice of infectious diseases. Churchill Livingstone. 2005; 881 $-2$.

14. Hemraj V, Diksha S, Avneet G. A review on commonly used biochemical test for bacteria. Innovare J Life Sci, 2013; 1(1): 1-7.

15. Tille, P. Bailey \& Scott's diagnostic microbiology-e-book. Elsevier Health Sciences, 2015.

16. Wayne PA. Clinical and Laboratory Standards Institute: Performance standards for antimicrobial susceptibility testing: $20^{\text {th }}$ informational supplement. CLSI document M100-S20. 2010.

17. Braoios A, Turatti TF, Meredija LC, Campos TR, Denadai $\mathrm{FH}$. Infeccoes do trato urinario em pacientes nao hospitalizados: etiologia e padrao de resistencia aos antimicrobianos. Jornal Brasileiro de Patologia e Medicina laboratorial, 2009; 45(6): 449-56. https:// doi.org/10.1590/S1676-24442009000600003

18. Kiffer CR, Camargo EC, Shimakura SE, Ribeiro PJ, Bailey TC, Pignatari AC, Monteiro AM. A spatial approach for the epidemiology of antibiotic use and resistance in community-based studies: the emergence of urban clusters of Escherichia coli quinolone resistance in Sao Paulo, Brasil. International Journal of Health Geographics. 2011; 10(1): 17. https:// doi.org/10.1186/1476-072X-10-17 